\title{
Online Activism Against Gender-Based Violence: How African Feminism is Using Twitter for Progress
}

\author{
Blessing Datiri \\ INSTITUTE OF LITERARY AND CULTURAL STUDIES, UNIVERSITY OF DEBRECEN
}

blessingdatiridagmail.com

Received: 15/09/2019

Accepted: 18/05/2020

\begin{abstract}
The chief goal of African feminism has been to better African women's dire conditions in a mainly patriarchal society. Over the last five years however, the tide appears to be turning as feminists across the continent make greater use of online platforms to work change. This paper discusses the ways in which African women are using Twitter to protest against the abusive conditions women face including early and forced marriages, domestic abuse, abduction, sexual assault, slavery and other forms of genderbased violence. Through the lens of three hashtag campaigns (\#BringBackOurGirls, \#JusticeforNoura and \#JusticeForOchanya), the paper examines the impact of twittering on African gender activism. Through Critical Discussion Analysis of selected tweets three key narratives emerged, constructed by the online activists who took part in the campaigns: Solidarity in Feminist Sisterhood; Gender Equality; and A Call for Justice. The tweets are analysed under these themes showing that the meanings constructed by the activists helped advance the African feminist cause. The paper concludes with the lessons to be drawn from the campaigns, which show social media's scope for advancing the goals of African feminism.
\end{abstract}

Keywords: \#BringBackOurGirls, \#JusticeForNoura, \#JusticeForOchanya, African Feminism, activism.

Corresponding author: Blessing Datiri, Institute of Literary and Cultural Studies (University of Debrecen) H-4032 Debrecen, Egyetem tér 1 (Hungary).

Suggested citation: Datiri, B. (2020). Online Activism Against Gender-Based Violence: How African Feminism is Using Twitter for Progress. Debats. Journal on Culture, Power and Society, 5, 271-286. DOI: http://doi.org/10.28939/iam.debats-en.2020-16

\section{INTRODUCTION}

Feminist movements around the world face challenges stemming from the political, social, economic, geographical and cultural contexts in which women live. African feminism, an exponent of feminist theory focusing on women's experience in the continent
(Ihle, 2009), It deals with uniquely difficult, existential problems. These include poor access to education, female genital mutilation, early marriages, domestic abuse and risk of death from conflict (Mutume, 2005). The agenda of African feminists, regardless of ethnicity or nationality, is a focus on Africa and the 
peculiar situation of women who live on or are from the continent (Toure, et al., 2003). Over the last decade, a key issue highlighted by African women is genderbased violence. Spontaneous online campaigns have served to highlight this issue. This paper presents a case study of three such campaigns and argues that online activism, through the themes and narratives it brings to the fore, shows potential for boosting progress in African feminists' quest to eradicate gender-based violence. It probes the social construction of meanings around the three campaigns and their implications for future campaigns.

Feminist activists in general have long fought for women's political, voting and legal rights; reproductive and parental care; contracts and ownership of property; protection from domestic violence, rape and sexual harassment or abuse; workplace rights including equal pay and maternity leave; and against other forms of the social and cultural discrimination women encounter (Drucker, 2018). Within Africa, feminism is not only philosophical and academic, it is also experiential and practical (Ahikire, 2014). In essence, African feminism tends to stress the daily experiences of African woman, particularly within the context of a hyper-patriarchal, conflict-prone setting. Ahikire (2014) suggests that African feminism therefore aims to provide the political strategy and intellectual backbone for the continent's women's movements.

After many African countries gained independence in the 1960s and 1970s, the feminist movement on the continent emerged as a subset of anti-colonial struggles in which nationalism was prioritised over feminism (Ahikire, 2014). From the late 80s through the 90s, the African feminist movement shifted the focus to fighting poverty, malnutrition and maternal and infant mortality (Maerten 2004). This period coincided with growing levels of theorisation and knowledge production on the continent (Mama, 2005) with growing output from indigenous Women's Studies faculties. African feminism has a track record of mobilising African women to address the special needs, conditions and aspirations of continental African women (Nkealah, 2016 and Baderoon and Decker, 2018).
This mobilisation has had its limitations, including waning enthusiasm for feminist ideals even within women's movements (Ahikire, 2014).

With the dawn of the $21^{\text {st }}$ century, new opportunities emerged for the African feminist movement to re-energise and draw up new strategies. In November 2006, over 100 African feminist thought leaders met in Accra, Ghana to draft a "Charter of Feminist Principles for African Feminists" (African Feminist Forum, 2006). The charter defines African feminists as women who either live in, work in or are from Africa who "fight for women's rights (...) and (...) focus on the lives of African women on the continent" (Charter of Feminist Principles for African Feminists, 2006, p.3). It sets out feminists' principles for African women, outlines institutional ethics for women's movement organisations on the continent and elevates feminist leadership. The advent of Information and Communication Technology (ICT), coupled with rising literacy rates among African women in the $21^{\text {st }}$ century, has provided great opportunities, tools and platforms that can be leveraged to advance the ideals of the African feminist charter.

Social media platforms have given women a new-found voice to address the conditions in which they live. With the use of hashtags, important issues are brought to the attention of masses of internet users throughout the world. In its simplicity, hashtag activism has emerged as one of the feminist movements' most potent forms of protests. It involves the use of the hashtag symbol (\#) followed by a word or phrase that identifies a key concept or topic of interest. Dixon (2014) asserts that through the algorithms of social media platforms, hashtags facilitate a search for related issues thereby amplifying discourse among online users.

The next section of this paper introduces the three hashtag campaigns on Twitter, \#JusticeForNoura, \#JusticeForOchanya and \#BringBackOurGirls that form the basis of the study. After introducing the three hashtag campaigns and the victims that inspired them, the paper analyses the common themes and narratives which emerged therefrom. Using Critical 
Discourse Analysis (CDA), selected tweets from the campaigns are discussed along the lines of three common themes: (i) Solidarity in Sisterhood; (ii) Human Rights Mean Gender Equality; and (iii) Advocacy for Justice. The paper also highlights major outcomes of the movements, including the impact they had on the victims, the government and the society. The concluding part identifies ways in which these three movements can influence future campaigns and the overall women's movement in Africa.

\section{Noura Hussein}

In May 2018, a young Sudanese woman named Noura Hussein Hammad, 19, was sentenced to death by hanging for the fatal stabbing of her 35-year old husband, Abdel Rahman Mohamed Hammad. While the government accused Noura of cold-blooded murder, she argued that her actions were in self-defence following an intense physical confrontation when Abdel was attempting to rape her for a second time. Her family had forced her into marriage at the age of 15, dashing Noura's hopes of completing her education to become a teacher. Noura escaped and took refuge at her aunt's where she remained for three years. Her father, having signed the marriage contract with Abdel, later tricked Noura into coming back home, after which she was handed over to Abdel against her wish (Mackintosh and Elgabir, 2018).

For her refusal to consummate the forced marriage, Abdel violently raped Noura in the presence of and with the help of his three male relatives, who held her down. The next day, Abdel attempted to rape Noura again, which led to the struggle in which he sustained fatal knife wounds (Amnesty International UK, 2018). Noura went back to her family immediately after and told them what had happened. She was handed over to the police and disowned by her family. Evidence presented at her trial, including medical forensics, corroborated Noura's claims of a fight between her and the deceased. However, the presiding judge found her guilty of murder by applying an archaic law that does not recognise marital rape. She was therefore convicted of pre-meditated murder and sentenced to death (Mackintosh and Elgabir, 2018 and Amnesty International UK, 2018).
Image 1

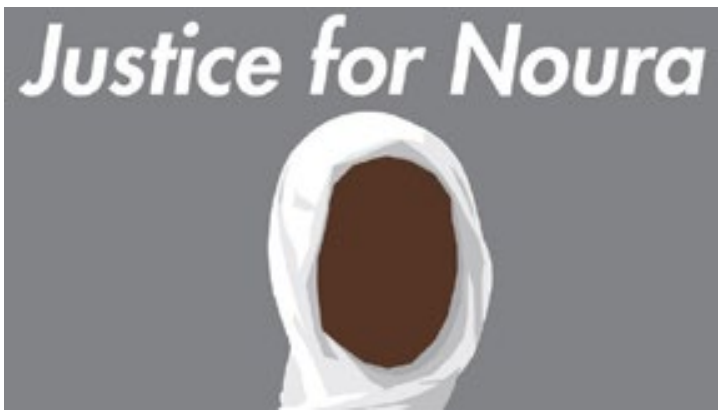

\section{\# JusticeForNoura}

By the time Noura's sentence was delivered on the $30^{\text {th }}$ April 2018, she had been imprisoned for about a year. Stories about her conviction began to spread among Sudanese on the encrypted messaging application, WhatsApp. On the $1^{\text {st }}$ May 2018 Sarah Elhassan, a Sudanese American freelance writer, shared the story on social media platform Instagram (CNN, 2018). Her post inspired the \#JusticeForNoura hashtag, which went viral on Twitter within days of its first use.

Noura Hussein's conviction exposed the extreme gender inequality in Sudan's legal system, where early marriage, forced marriage and marital rape are socially and legally permissible (Amnesty International UK, 2018). When the story was first shared on Twitter, it quickly gained attention, sparking a global outcry and demands to spare Noura's life. Internet platforms went viral with the \#JusticeForNoura hashtag becoming the central rallying point others used by campaigners include \#JusticeForIsraa and \#NouraHussein.

\section{Elizabeth Ochanya Ogbanje}

Elizabeth Ochanya Ogbanje, 13, died in October 2018 from Vesico-Vaginal Fistula (VVF) and other health complications resulting from over five years of serial rape (starting when she was only eight) by her uncle, Andrew Ogbuja, and his son, Victor Ogbuja (Adaoyichie, October, 122018 and Ameh, October, 23 2018). Ochanya was a brilliant young girl who had a passion for school from a tender age. Due to 
inadequate educational facilities in their community, Ochanya's parents sent her to live with her uncle in Markudi, a city in Central Nigeria (Adaoyichie, 2018). The sexual abuse began with Victor, the son, who had threatened Ochanya not to tell anyone what was happening. When he was caught by his sister, who reported the case to their father, Victor was merely scolded. Soon afterwards, the father himself began to abuse the little girl (Adaoyichie, 2018).

Ochanya's health began to deteriorate in January 2018 and she was admitted to hospital where she told journalists of her ordeal "When I was eight years old, the son [Victor] started sleeping with me and when his sister caught him, she reported him to their father and the father scolded him. From then on, the father also started sleeping with me.... I told my mother; that is why we brought this case here. I want my health back" ("Rape case: Justice,"2018, para. 6). Unfortunately, she died a few months after.

Image 2

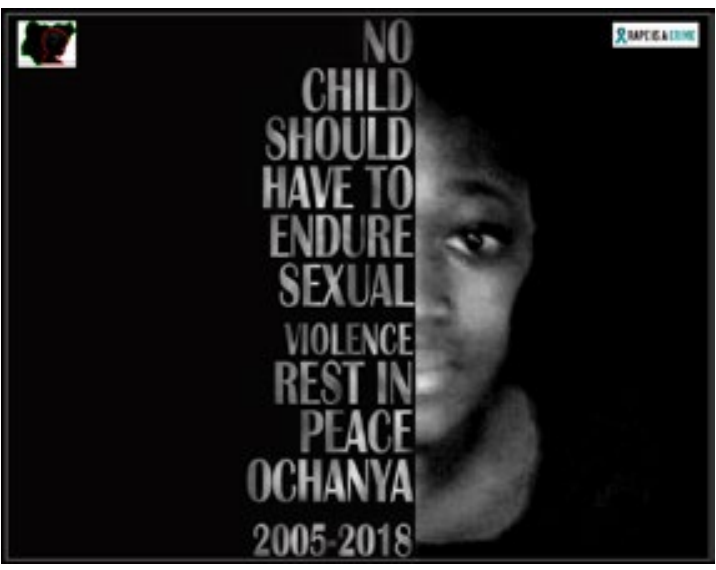

\section{\#JusticeForOchanya}

News of Ochanya's death enraged the Nigerian populace, leading to an uproar on social media. In line with the concurrent \#JusticeForNoura campaign, Nigerians coined \#JusticeForOchanya to demand the immediate arrest and prosecution of her rapists. Ochanya's tragic story was publicly shared on Facebook by a user familiar with the background to the story. Thereafter the story began to appear on Nigerian blogs in October 2018, blog posts that were later shared on Twitter were accompanied by the hashtag.

\section{Chibok Girls}

On the night of the $14^{\text {th }}$ April 2014, 276 teenage Secondary School girls between the ages of 14 and 17 were kidnapped by Boko Haram terrorists from their dormitory in Chibok, a small town in NorthEastern Nigeria (Omeni, 2017; Fox News, 2014). The girls were reported to have spent the day studying in preparation for their final exams. Boko Haram, the radical Islamist organisation, claimed responsibility shortly after (Omeni, 2017 and Smith, 2015). A video released by the militant group called the abducted girls the sect's 'slaves' (Smith, 2015: 186) and also taunted the Nigerian government, human rights organisations and the international community (Hill: 2014, Smith 2015 and Sahara TV, 2014). With their main operational base in North-Eastern Nigeria, Boko Haram has also been active in Chad, Niger and Cameroon (Bureau of Counter-Terrorism, 2014).

Boko Haram strongly opposes Western education and democracy, using jihad to establish an Islamic caliphate in Nigeria and neighbouring countries (Azumah, 2015). The mass abduction of the Chibok school girls was intended to show the sect's opposition to Western education, especially for girls and women (Chiluwa, 2015).

Image 3

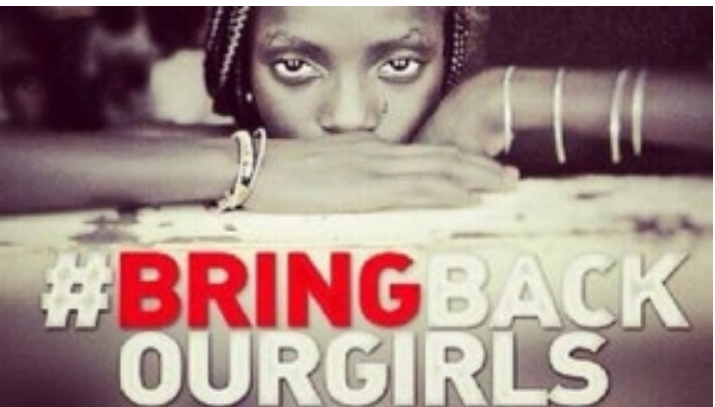




\section{\#BringBackOurGirls}

Nigerians were shocked by the government's indifference and inaction in the days following the abduction of the 276 schoolgirls from Chibok (Pendergrass, 2015). This happened against the background of a steady rise in Boko Haram's terrorist attacks. In previous attacks, Boko Haram had gone on a rampage, sacking villages, killing people and destroying properties. The Chibok abductions were the terrorist group's most daring act yet. Outraged by the Nigerian Government's sluggish response, Obi Ezekwesili, a former Minister of Education, called a press conference to demand action. In her speech, she called on the government to "Bring back our girls" (Maxfield, 2015). This inspired a tweet from a Nigerian lawyer with the viral hashtag \#BringBackOurgirls. Other hashtags bearing on this campaign include \#RealMenDon'tBuyGirls, \#BringBackOurDaughters, \#ChildNotBride and \#BokoHaram.

\section{METHODOLOGY}

Hashtags are a feature of virtually all of the major social media platforms. A hashtag campaign can originate from any of the platforms, depending on the promoter's preference, before finding its way on to other sites. The three hashtags analysed in this study were prominent on three major platforms: Facebook, Instagram, and Twitter. The paper focuses on how each of the campaigns was conducted on Twitter because this was the social media platform on which the three hashtags gained most momentum.

For the analysis, online hashtag tracking tools (mainly from www.socialert.net) were used to aggregate thousands of tweets for each hashtag, depending on how many views and impressions they generated over a given timeframe and the thematic areas they covered, including: feminism; womanhood; human rights; gender equality; gender-based violence. Using search functions on the Twitter desktop version, a few dozens of these tweets from each hashtag were randomly selected for analysis. The keywords that were searched for were chosen to ensure the sample was representative of general views in the selected tweet population. Although randomly selected, the analysed tweets were also deliberately selected from a pool that covered the dominant narratives of the campaign. Selected tweets for each campaign were coded as follows: TWTJN represents Twitter posts related to \#JusticeForNoura; TWTJO stands for Twitter posts on \#JusticeForOchanya and TWTBBOG are for Twitter posts from \#BringBackOurGirls. Thirty-four analysed tweets are serially numbered in the order in which they appear in the paper, stripped of their author: TWTJN 1-14; TWTJO 1-10 and TWTBBOG 1-10. One should note that other languages were also used for the three campaigns such as Arabic, Spanish, German and Nigerian Pidgin English. However, only Twitter posts in English were analysed because most of the participants in the campaign tweeted in English.

For each hashtag, a timeline was set using the aforementioned online tools as shown in the table 1 .

Critical Discourse Analysis (CDA) as a method provided the theoretical framework for analysing the selected tweets, which are presented exactly as the users published them without any corrections. An interdisciplinary approach to discourse analysis may include examining collective interactions, texts and/ or social practices at the local, institutional, cultural, political, and societal levels (Hansen and Machin, 2013). CDA considers language as a form of societal practice that enables the investigation of how societal power relations are established. It highlights the rhetoric and issues of structural inequalities, exploitation, discrimination and power asymmetries in societal strata by providing insights into the way discourse resists socio-political inequality (Wodak and Michael, 2001).

\section{DISCOURSE ANALYSIS OF THE CAMPAIGNS}

From the onset, the three campaigns share a commonality of victims, girls and women, living in Africa. Their stories reflect the prevailing experiences of millions of their peers across the continent. What Stolz and Faure (1997) term "the secret suffering of African women" is in a sense no longer secret. Stories of sexual 
Table 1 Data presentation

\begin{tabular}{|c|c|c|c|}
\hline & \#JusticeForNoura & \#JusticeForOchanya & \#BringBackOurGirls \\
\hline Timeline & $\begin{array}{l}21^{\text {st }} \text { May } 2018- \\
12^{\text {th }} \text { May } 2019\end{array}$ & $\begin{array}{c}29^{\text {th }} \text { October } 2018 \text { - } \\
13^{\text {th }} \text { May } 2019\end{array}$ & $\begin{array}{l}31^{\text {st }} \text { May } 2014- \\
15^{\text {th }} \text { May } 2019\end{array}$ \\
\hline $\begin{array}{l}\text { Selected Posts during } \\
\text { period }\end{array}$ & 5,766 & 2,971 & 33,664 \\
\hline $\begin{array}{c}\text { Selected Users during } \\
\text { period }\end{array}$ & 4,341 & 1,996 & 17,749 \\
\hline Reach* & $31,479,693$ & $17,587,494$ & $177,622,591$ \\
\hline Impressions** & $43,067,940$ & $36,537,351$ & $525,663,669$ \\
\hline Selected Posts Analysed & 14 & 10 & 10 \\
\hline
\end{tabular}

${ }^{*}$ Reach is the total number of people who viewed these hashtags within the stated date spans.

${ }^{* *}$ Impressions represent the total number of times the hashtags were tweeted and re-tweeted.

violence and other forms of domestic abuse are covered practically daily in African mainstream media, blogs and social media platforms. When the stories of the Chibok girls, Noura and Ochanya emerged, they were essentially to an audience already aware of such horrifying abuse. They naturally formed the seed activists for each campaign. One can assume that before the widespread use of social media, these present-day online activists might have felt powerless to do anything about the terrible stories they heard in the media. Yet with a smartphone in their hands, they became voices - albeit small ones - that swelled the chorus in the "Twitterverse" (Ingerson K. and Bruce K., 2013). Just as every drop of water helps make an ocean, so each activist's voice helps build meanings and discourse in a hashtag campaign.

\section{Linguistic and Rhetorical Characteristics of the Tweets}

On Twitter, the masses in their millions have taken over the power to construct meanings, set narratives and direct the news cycle, away from the central nodes that hitherto controlled the traditional media (Poster, 2009). Other scholars have questioned this potency of online social media platforms ((Jenkins 2006; Mason 2008; Shirky2009), arguing that social media platforms have sustained and even strengthened pre-existing narrative-imposing power structures. Nevertheless, Twitter activists do feel empowered 
to air their opinion. Previously confined to just 140 characters, Twitter users now have double that to succinctly post their views. These opinions are not subject to any editorial strictures or the whims of any grammar police.

The thousands of tweets for the three hashtags are mainly 280 characters long or less, this figure being the maximum allowed. Except for tweets taken from institutional posters, most of the tweets share a common contextual background and are typically expressed in colloquial language, with attendant grammatical and punctuation errors. Remarkably, the nouns and pronouns used by the overwhelming majority of the posters almost wholly refer to the victims. Sometimes referred to by their first names (Noura or Ochanya), or collectively (Chibok girls), whenever "she" or "they" were used by posters, the name(s) of the victim(s) is inherent. Posters were generally self-effacing and whenever they used first person pronouns it was always to highlight their own solidarity or identification with the victim's plight.

Although activists expressed strong disapproval of the evil done to the victims, adjectives expressing 'shock' were sparingly used in all of the three campaigns. This underscores the activists' familiarity with such experiences. Yet the strong disapproval expressed also showed that the activists' familiarity with these acts of violence had not numbed them to the harm caused by the evil deeds.

Posters of the three hashtags mostly employed an expressive style seemingly lacking in rhetorical value. In most posters, the main goal does not seem to be to persuade others to join the campaign. Rather, they were simple personal views of the 'facts'. They typically paraphrase their own understanding of the situation followed by ways in which they think it important to show urgency or call for action.. Although the posters seem to deliberately avoid persuading readers, they nevertheless appeal to emotions by using personalised terms to show the victim's plight. Using selected tweets, the next part of this paper will delve deeper into the narratives and meanings constructed by the posters through three themes: solidarity; gender equality; the quest for justice.

\section{Solidarity in Feminist Sisterhood}

Sisterhood is a bond between women who share a common goal to uplift, emancipate and empower other women by uniting to foster social change. As in the solidarity stressed by labour movements, feminist solidarity is critical in the fight for gender equality and social development. It is also important within local politics in merging women's movements and activists on the one hand, and international feminist advancement on the other. Sisterhood was emphasised in the early era of 'Second Wave Feminism' (Morgan, 1970) but became increasingly criticised in 'Third Wave Feminism'. Through their experience as Chicana women, Moraga and Anzaldúa (1981) have questioned the ideas of solidarity within the feminist movement, considering white feminists as essentially part of a racial hierarchy that dominated women of colour. Other scholars have challenged the vertical relationships that exist among women and questioned the possibility of sisterhood within such societal structures (Goldenberg, 2007; Frye 1996).

In what some scholars have termed "Fourth Wave Feminism" (Munro, 2013), enabled by the internet and social media, it is may be worth revisiting the ideals of strengthening the solidarity bonds among women. Concepts of solidarity and sisterhood are particularly relevant for African women who live their lives in a male supremacist culture where they are expected to wholly depend on men. Through social media, they can challenge this culture and protest for social change. They can be joined in this endeavour by 'sisters' from around the world as the sisterhood bond goes beyond geographies. Data captured by socialert.net show that the three campaigns were actively engaging women from countries throughout Africa, Europe, North America, and Australasia.

The most common theme across the three campaigns was the identification of the respective victims as 'sister(s)' by people who have never met them. In the \#JusticeForNoura campaign, feminist activists 
called for clemency and stood in solidarity with the victim, whom they addressed as their 'sister in humanity' irrespective of their geographical or historical backgrounds:

TWTJN 1: "Noura is being sentenced to death for stabbing and killing a man whom her family forced her to marry and wanted to rape her for the second time. I stand with my sister"

The TWTJN1 poster rejects the idea that Mohamed Hammad was Noura's husband. Although the official story portrays her as a cold-blooded murderer who took her 'husband's' life, this poster rejects that narrative, choosing instead to address Hammad as "a man" who was attempting to rape her a second time. When the poster uses the first-person pronoun "my", it is to underscore the feminist solidarity that she feels with Noura. The use of first-person pronouns (in singular and plural forms) can convey solidarity within a tweet in a powerful way. Searching each of the hashtags along with the word 'sister' yields tens of thousands of results containing many variations, including "my sister" (as in TWTJN 2, TWTJN 3, TWTJO 4 and TWTBBOG 2); "my or our sister" (as in TWTJN 3, TWTJN5,TWTJO 1, TWTJO 2, TWTJO 3, TWTJO 4, TWTJO 5, TWTBBOG 1, TWTBBOG 3, TWTBBOG 5); and "sisterhood" (as in TWTBBOG 3, TWTBBOG 4 and TWTBBOG 7).

TWTJN 2: “\#JusticeForNoura DC Rally will be held this Saturday!!! Noura, a young girl in Sudan is a victim of rape and is being sentenced to death after killing her attacker! A sister rally will be held in Sydney, Australia (confirmed) and a London one is in the works and TBA!!"

Although Noura was an adult at the time (aged 19), most activists on the campaign consciously chose to refer to her as a "young girl", a key rhetorical tactic to make the reader think of a middle-aged man raping a minor (See TWTJN 2 and TWTJN 3). This was employed by hundreds of posters who called Noura a "Sudanese girl" or "young girl". Surprisingly, activists who took part in the \#JusticeForOchanya campaign did not rely heavily on this tactic even though Ochanya was actually a minor, her abuse beginning when she was just eight. Only a few posters (as in TWTJO 5 and TWTJO 7) stressed that
Ochanya was a minor. The \#BringBackOurGirls campaign already highlights "girls" within the hashtag, confronting the reader with troubling imagery of hundreds of schoolgirls being dragged from their dormitory into terrorist encampments.

TWTJN 3: "Noura is a Sudanese girl that's been sentenced to death for murdering a man who tried to rape her for the second time out of selfdefense. I'm a woman and I support my fellow African sister \#JusticeForNoura".

For many African feminist activists taking part in these campaigns, it was important to underscore the common African heritage they share with the victims. TWTJN3 poster identifies with Noura as "my fellow African sister". Targeted searches across the three hashtags yielded thousands of such identifiers (also represented by TWTJN 5). The African feminist activists who expressed this regional solidarity saw themselves as part of a women's movement, in solidarity with other women, fighting and challenging existing power structures.

TWTJN 4: "In Zaynub's words, Noura Hussein is our "sister in humanity." We can't let her die for defending herself against the man who raped her. \#JusticeForNouraActive petitions: https:// change.org/p/justice-for-noura-maritalrapedeathsentence-sudan".

TWTJN 5: "My African sister, you are a symbol of many women... \#JusticeForNoura"

Posters of TWTJN 4 and TWTJN 5 consider the subject of their campaign not just as a victim but also as an object of their shared humanity and a symbol, a representative sample of the huge daily challenges facing millions of fellow African women. Participants empathise with the victim's plight and instantly forge a link with her. All three campaigns can be seen as part of the bond of online African feminism.

TWTJO 1: “\#JusticeForOchanya We Demand Justice for Our Sister OCHANYA. As a matter of fact, both the Man, Son and his wife and anybody involved should be brought to book. 
This also tells us that we must all be vigilant to the activities in neighbors houses. \#observe"

The activist author of TWTJO 1 is making a call to action for justice on behalf of "our sister" Ochanya, whose name is capitalised. The poster sees society bearing a responsibility to look out for and report other cases of abuse that may be occurring within the neighbourhood, including a secondary hashtag "\#observe". In essence, we as society owe it to Ochanya because she is "Our Sister".

TWTJO 2: "Ochanya is our own Sister! We won't stop until our voice is heard \#JusticeForOchanya"

TWTJO 3:"She had dreams, aspirations and a bright future. But it was truncated. She's Our sister. \#JusticeForOchanya";

TWTJO 4: "Ochanya is my sister, your sister, my neighbor, your neighbor. She deserves justice \#JusticeForOchanya"

Posters of TWTJO 2, TWTJO 3 and TWTJO 4 continue the narrative from TWTJO 1. Because Ochanya is "Our Sister" it behoves us to ensure our voices represent her, and many like her. She is presented as any of us, a sister with "dreams, aspirations and a bright future" who unfortunately would not live to fulfil them. Much the same sentiment is expressed in TWTJO 5 below.

TWTJO 5: "Please let's join hands together and get \#JusticeForOchanya. Say no to rape. Say no to child molestation. That father and son should dwell in jail all their lives or die by hanging, no human being should go through what Ochanya went through. She was once a daughter, a sister".

The sisterhood solidarity that laced the \#BringBackOurGirls campaign was so effective that it influenced many subsequent feminist hashtag campaigns, as can be seen in the analyses of \#JusticeForNoura and \#JusticeForOchanya. The Feminist discourse on the missing schoolgirls is marked by references to emotional attachment to the 276 girls who are addressed as sisters.

TWTBBOG 1: "Let that sink in almost a year later our sisters never got home THE WORLD JUST FORGOT \#BringBackOurGirls";
TWTBBOG 1 expresses disappointment that the world may have forgotten about the Chibok girls a year after their abduction. It has been over six years now since the abductions, many twitter activists still raise this concern on each anniversary of the girls' abductions (April $14^{\text {th }}$ ). Some celebrate the rescue or escape of some of their "sisters" but still add their voices to the need to rescue all of the others. As TWTBBOG 2 states, 70 of the girls have been reunited with their families, "faith" needs to be put into action "NOW" for the release of the others.

TWTBBOG 2: "Standing with my sister in solidarity...raising our voices. FAITH IN ACTION! \#70 of the 219 \#BringBackOurGirls NOW!"

In TWTBBOG 3, TWTBBOG 4, TWTBBOG 5, TWTBBOG 6 and $T W T B B O G$ 7, the sisterhood that binds the activists with the victims and other women "worldwide" is worth highlighting. TWTBBOG 5 offers prayers for the safe return of "our sisters" while TWTBBOG 6 poster tweeted female members of the US Congress holding placards of the \#BringBackOurGirls to show their own solidarity with the "worldwide" movement. In the poster, showing female members of parliament of a powerful country supporting the movement symbolises the strength needed to take on the power structures that allowed the Chibok abductions to happen in the first place.

TWTBBOG 3: "Our Sisterhood is worldwide. \#BringBackOurGirls \#bambiepower"

TWTBBOG 4:"\#BringBackOurGirls This is about sisterhood"

TWTBBOG 5: “\#Sisterhood \#BringBackOurGirls Praying that our sisters will all come back safe and sound"

TWTBBOG 6: "The women of the Senate fighting to \#BringBackOurGirls: "Congressional sisterhood a powerful voice for the voiceless" http://cnn. it/1gnQ9Q6".

TWTBBOG 7: "I speak from the heart of sisterhood. From the sensitivity of being a woman and the transparence of empathy. \#BringBackOurGirls". 
These power structures perpetuate atrocities on "womanhood" by denying them "protection", and may cause lack of socio-economic progress, according to TWTBBOG 8.

TWTBBOG 8: "Listen to me a country that does not offer protection for womanhood will never rise. \#BringBackOurGirls"

With deliberate narratives stressing common bonds, women used the online media to herald a new dawn of African feminism, with social media platforms helping them to forge worldwide links. At root, African feminists are sisters who may live in different countries or continents but are linked by the online community to celebrate their womanhood and air their views against the most common forms of abuse, injustice and inequity. The act of solidarity and sisterhood was not just expressed on the social media platforms, as we can see with the poster of TWTJN 6 taking steps offline to provide support to one of the victims:

TWTJN 6: "I set up an email account to send letters of support to Noura to keep her morale up. Letters will be printed and delivered to her. Email your letter of support to JusticeForNoura@ gmail.com. Letters should be in Arabic, but if you can't, send in English anyway. \#JusticeForNoura".

Hundreds of users responded to TWTJN 6, with willing activists volunteering to translate the letters from English to Arabic and vice versa and to help in the compilation process to ensure that Noura felt her life was valued by her sisters around the world. Other activists showed support by sending in their pictures holding a \#JusticeForNoura placard or by signing the change.org petition urging Sudanese authorities to free Noura.

Sometimes the stigma of victimhood discourages abused women from sharing their experiences in public (Kennedy and Prock, 2016; Berkey L. et al, 2000). These three campaigns find ways to reverse the narrative, referring to the victims as "sisters" and "heroes" who should be celebrated for being strong women. Noura for example is praised by many activists on Twitter for fighting her many foes. She stood up to the system ("her oppressor") according to TWTJN 7, who expresses "hope" that she prevails.

TWTJN 7: “\#JusticeForNoura Noura Hussein is a feminist hero for standing up to her oppressor. I hope she wins her appeal"

The poster of TWTJN 7 does not define what a "feminist hero" is but directly links it to "standing up to" an oppressor. This implies that women who daily battle against the social power structures ranged against them are heroines who should be lauded for their efforts.

\section{Human Rights Mean Gender Equality}

The aspirations of feminism are aligned with basic principles of human rights (Parisi, 2010). Women movements push for freedom, protection from gender-based violence, end to discrimination, right to education and healthcare, rights to vote, participate in political leadership, to own property, to earn equal pay, etc. The victims that inspired the three hashtags are women or girls who have endured tragic violations of their basic human rights. Noura was denied access to education and forced to marry a man when she was still a minor. She was violently raped. Ochanya made the sacrifice of living away from her parents just to gain an education that should have been her right. The men she was entrusted to serially raped her for over five years, starting when she was only eight. In the end, she lost her right to life. The 276 Chibok girls were seized at school and dragged off to captivity in terrorist camps. They symbolised the strength needed to denounce forced marriage, rape, religious conversion at gun-point, and psychological torture.

African feminism understands that women liberation on the continent cannot be achieved without radical changes to the way women's rights are addressed (African Feminist Charter, 2006). This realisation becomes more obvious when considering the huge interest sparked by the three hashtag campaigns and the violations of human rights that they covered.

Adolescent sexual abuse in Nigeria is a criminal offence under Chapter 21 of the nation's Criminal Code in which the accepted age of consent is 18 (Nigerian Criminal 
Code Act, 1990). However, according to the United Nations Children's Fund (UNICEF, 2014) one in four girls will experience some form of sexual abuse before she turns 18. The UNICEF report further states that six out of ten children in Nigeria experience one or more forms of abuse (physical, emotional or sexual) before reaching the age of consent. While expressing outrage at the abuse young Ochanya suffered, online activists vehemently stated that every young girl has 'a right to her body' and needs to be protected from being raped.

For the TWTJO 6 poster, the discourse on Ochanya extends beyond her as a single victim. By calling for a "fight" for other the "Ochanya's out there" (sic), the poster recognises that there are other girls, and women whose rights to their "body", "thoughts" and "dreams" are being violated. While Ochanya will not live to fulfil hers, activists must fight to protect these basic rights of women. TWTJO 7 similarly underscores the point that many other girls are - like Ochanya - being raped and abused, while expressing the hope that such victims will be encouraged to speak out.

TWTJO 6: "she has a right to her body Right to her thoughts Right to her dreams she couldn't live to fulfil... Fight for Ochanya's out there, it could be your daughter, sister, friend. Fight against "RAPE"...."

TWTJO 7: "Many people are currently going through what Ochanya went through for 5 years of her life. The first step that must be taken in reducing sexual assaults on children is to support victims to have the courage to openly speak about their experiences. \#JusticeForOchanya".

According to the narrative being set by these activists, the rape culture is widespread and must be confronted. In the case of Noura, even within marriage, rape occurs and it is unacceptable. TWTJN 8 and TWTJN 9 echo this narrative to state that no form of rape should ever be acceptable, even when committed under the guise of "marriage". When a supposed "husband" forcefully has intercourse with his "wife" it is still sexual violence which violates the woman's rights. These simple narratives are imbued with a strong rhetorical discourse that clarifies what the victim's rights are and how they must be protected.

TWTJN 8: "She's a human, she's a woman and she stands for resistance. Rape is not okay, whether the partners are married or not. It is wrong!"

TWTJN 9: "Noura Hussein was a victim of severe sexual violence. Her rights must be respected and she deserves care, support and protection.. \#JusticeForNoura"

According to the TWTJN 10 poster, the narratives set by "movement" participants who showed "solidarity" with the victim helped in freeing Noura. Expressed with political finesse, the author appreciated those who "stood up" for justice and "made human rights matter".

TWTJN 10: "Movements matter. Solidarity matters. Collective organizing works. Feminist organizing makes the world a better place. Thank you to all the women who stood up for \#JusticeForNoura and made human rights matter"

The 276 Chibok girls had their rights collectively and individually violated and with many of them still in captivity, these violations continue. TWTBBOG 9 refers to the "womanhood" of abducted girls who remain in captivity, a subtle reference to the length of time for which they have been away. Although they were taken as "girls", many of them are now "women" and their dignity is bruised by endless sexual abuse.

TWTBBOG 9: "The 234 girls who are still being held hostage are silently mourning their abused pride and womanhood. We must \#BringBackOurGirls"

By tying the abuse and violations of victims to human rights, campaigners succeed in drawing and sustaining the level of outrage needed to effect change. This creates a coalition that goes beyond gender. Men became important participants in the advocacy for the Chibok girls, introducing their own mini-hashtags such as \#RealMenDon'tBuyGirls. Since women's rights are human rights (Clinton, 1995), men will find a stake joining feminists to defend these rights. 


\section{Advocacy for Justice}

Two of the three hashtags prominently use the word "Justice", a virtue commonly accepted by society. The feminist activists recognise that justice is not necessarily what comes out of the existing judicial system. The distinction is highlighted in many tweets, particularly in the \#JusticeForNoura campaign in which archaic local laws still prevail in the Sudanese legal system. Because the legal system does not contemplate the possibility of rape within marriage, Noura's defence was dismissed out of hand by the judge. Instead of being seen as a rape victim who was trying to defend herself against a second rape attempt, Noura was treated as a cold-blooded murderer. The movement insists that true justice must be done. For the TWTJN 11 poster, Noura's case should not be seen through the eyes of Sudanese jurisprudence. Where the legal system permits forced early marriages with the "consent" of a girl's parents, the poster considers the marriage "illegal". Therefore, Noura is not the perpetrator of the violence but its victim. She was not only the victim of this illegal marriage; she was also a victim of an "injustice" system. The abuse she endured left physical and mental scars.

TWTJN 11: “\#JusticeForNoura A victim of rape, a victim of illegal child marriage, a victim of physical and mental abuse, and when she defended herself, she became victim of injustice"

TWTJN 12 captures the frantic attempt of an activist to keep the momentum of the movement going, urging readers to join the effort and show their "solidarity". The poster equally rejects the legal recognition accorded Noura's "husband", referring to him polemically as Noura's "rapist".

TWTJN 12: "People all around the world are calling for \#JusticeForNoura. There are only two days left to appeal her sentence of execution for stabbing her rapist. Keep sending your solidarity pics in, and sign here: http://change.org/JusticeForNoura \#JusticeForNoura \#Justice4Noura"

TWTJN 13: "As the subject of rape and sexual abuse, Noura should be treated as a victim and not a criminal and be given justice as she has survived child marriage, forced marriage and marital rape \#JusticeForNoura"

TWTJN 13 joins others to underscore this point. The accused, Noura, should not be treated as an aggressor or criminal, rather she is the victim of a system that allows forced child marriages. Noura survived the system and should be "given justice". Justice here does not mean as determined by Sudanese law. Instead, it means justice in terms of the international human rights protecting victims.

Advocacy for justice (economic, political and cultural) will likely remain a key theme of African feminism for many years to come. As calls poured in demanding clemency and pardon for Noura, activists condemned the initial sentence of death by hanging passed on the victim - who was often described as a 'rape survivor' (as in TWTJN 14). The posters expressed optimism that the death sentence would be overturned given that women who survive rape are victims and should not be put on trial.

TWTJN 14: "I... urge the Sudanese government to pardon rape victim Noura Hussein and show the world, that women who are brutally raped, are the real victims. \#JusticeForNoura"

Other activists called on people in positions of authority to help keep the movement going and maintain the narrative as the date for Noura's appeal approached.

TWTJN 15: "We can all support by raising awareness, speaking to authorities, and continuing to keep the issue at the forefront as the team fights for her appeal \#JusticeForNoura"

True justice requires that rapists must not go free. The activist movement, focused on the girl child Ochanya, strongly emphasised the need to protect victims from sexual predation by ensuring that child molesters are prosecuted (as in TWTJO 8).

TWTJO 8: "Pedophiles/Child molesters should be brought to book. No child should be a victim of molestation... \#JusticeForOchanya" 
The poster of TWTJO 9 conveys the impact that Ochanya's story had for the tweeter. Hundreds of the tweets from the three hashtags reveal this personal identification with the victim's plight. The post highlights the absurdity of society judging the victims rather than their predators.

TWTJO 9: "This story strengthens my resolve to be part of the fight against child molestation in Nigeria. It's a huge part of our society but its hidden because we judge the victim and not the perpetrator. \#JusticeForOchanya"

TWTJO 10 humanises the victim, whose freedoms have been snatched away by perpetrators who must not be allowed to continually evade justice.

TWTJO 10: "She had dreams too, just like each and every one of us. [heartbreaks] For Ochanya, and for every single victim of sexual assault, there must be justice. These vile rapists cannot continue freely with their own lives. \#JusticeForOchanya"

Advocacy for justice works if women come together to speak against violence and injustice. The \#BringBackOurGirls galvanised support for the war against Boko Haram as the only way to obtain justice for all the atrocities they committed. The poster of TWTBBOG 10 argues that women are capable of exercising significant collective power when they organise. The posts issue a rallying cry to feminist activists to confront violence.

TWTBBOG 10:\#Bringbackourgirls shows power women have when they organize. Stand up to violence and support feminist activism now \#fearless..."

One of the commonest challenges women face - regardless of race, class or geography - is sexual abuse. For decades men, powerful and ordinary, had gotten away with sexual assault and harassment of women. As more and more women summon the courage to tell their stories, a new era has dawned in which justice is expected against perpetrators. A common hashtag that has spurred this movement is \#MeToo through which women share their stories, support one another and jointly confront misogyny (Mendes et al., 2018).

\section{OUTCOMES OF THE CAMPAIGNS}

These three campaigns, like other gender activism carried out on social media platforms, have had a real impact on the victims that inspired them, as well as on local society and on government policies. The hashtag campaigns drew sufficient attention to critical issues for the mainstream media to take notice. Stories about the hashtags hit the headlines both locally and internationally, creating sufficient pressure for government action (Segun and Muscati, 2015).

\#JusticeForNoura launched a female emancipation revolution in Sudan in 2018, the campaigns' pragmatic calls for action led to review of some of the archaic laws used in convicting Noura. UN Gender Equality Statistics and the Human Development Index still rank Sudan $165^{\text {th }}$ out of 188 countries in terms of the treatment of women and of children as young as 10 years' old - both of whom can still be forced into marriage. However, the movement launched by \#JusticeForNoura has forced Sudan to launch a modernisation of their Family Law Act with changes that include raising the age of marriage to 18 , requiring consent of the woman before marriage and denunciation of cases of marital rape. Pressure from various sources ensured Noura's conviction was commuted to manslaughter, with a reduction from the maximum penalty to five-year imprisonment, in addition to a monetary fine of 337,500 Sudanese Pounds.

\#JusticeForOchanya was a campaign for a victim who came to a tragic end. Its focus was to ensure the perpetrators of her abuse were brought to justice. It succeeded in ensuring the alleged rapists were arrested and arraigned in court through massively attended offline protests. The campaign also drew renewed attention to the enforcement of Nigeria's Child Rights Act which aims at improving the investigation, prosecution and handling of child harassment, child sexual abuse, neglect, exploitation, and so forth in a manner that prevents further trauma to the child.

\#BringBackOurGirls was the most viral of the three campaigns. It had a far-reaching impact not only on the case of the Chibok girls but also on the state of 
governance in Nigeria, the right of the girl child to safe education and the conduct of other feminist campaigns online. Government action occasioned by the campaign's protest led to the rescue and release of dozens of the girls, some of whom have received asylum in certain Western nations to complete their education.

These three hashtag campaigns were turning points for African feminism. All three occurring over the last five years, they convey lessons on how effectively the feminist cause can be advanced to benefit women throughout Africa. Overcoming deeply-ingrained cultural prejudices is hard, however the changes wrought by these hashtags show that it is far from impossible.

\section{CONCLUSIONS}

Activism and/or social movement involve the use of action to achieve political or social change. With growing internet penetration across Africa, feminist activists on the continent have been handed a new weapon in their struggle. It is one that simplifies mobilisation of the women's movement. The three hashtags analysed (\#JusticeForNoura, \#JusticeForOchanya and \#BringBackOurGirls) have shown the huge scope hashtag activism holds for African feminists in fostering, participating, and conducting protest. Activists have taken advantage of the new opportunities brought by social media and the internet to spread their causes by taking control of the social construction of meanings and narratives around the issues they care about. The three hashtag campaigns led the public discussion on the issue through three key themes:: (1) solidarity in feminist sisterhood; (2) elevation of gender equality; (3) a call for justice for the victims of abuse. Thanks to the relative successes of these hashtags, African feminism now has a powerful medium at its disposal to give a strong voice to those who formerly suffered in silence.

From the three hashtags analysed, feminist social media activism played two roles. First, it served as a society watchdog. The government and judicial system in affected countries were called upon to either mete out justice, show clemency or provide security for their citizens. A fair slice of the online population took part in demanding democracy and good governance by speaking the truth, confronting corruption, and standing up against injustice. Second, it raised awareness globally by beaming a light on the conditions under which women live in Africa. The widespread use of the hashtags on social media influenced worldwide mainstream media coverage of the campaigns that inspired the hashtags.

The three campaigns show that for a cause to be turned into action, topics should elicit empathy. When online users can automatically find a connection to the cause, they promote it. This ensures that even men become feminists and demand better treatment for women. The cultural/traditional setting in Africa makes the man the head of the household and community. Men need to be convinced of the need to empower women in order to foster the advancement of society as a whole.

\section{BIBLIOGRAPHIC REFERENCES}

Adaoyiche, G. (2018, October 12). The untold story of how 13-yr-old Ochanya died while seeking an Education. Pulse Nigeria Retrieved from https://www.pulse.ng/the-untold-story-of-how-13-yr-old-ochanya-died-whileseeking-an-education/b06tw0z.

African Feminist Forum (2006) Charter of Feminist Principles for African Feminists Retrieved from: http://awdf.org/ wp-content/uploads/AFF-Feminist-Charter-Digital-\%C3\%A2\%C2\%80\%C2\%93-English.pdf.

Ahikire, J. (2014) "African Feminism in Context: Reflections on the Legitimation Battles, Victories and Reversals". Feminist Africa, 19, 7-23. 
Ameh, C. G (2018, October 23) Nigerians demand justice for 13-yr-old Ochanya Ogbaje allegedly raped to death by father, son in Benue Daily Post Nigeria Retrieved from https://dailypost.ng/2018/10/23/nigerians-demand-justice13-yr-old-ochanya-ogbaje-allegedly-raped-death-father-son-benue/.

Amnesty International UK (2018) "Justice for Noura Hussein" Retrieved from https://www.amnesty.org.uk/justicenoura-hussein.

Azumah, J. (2015) 'Boko Haram in Retrospect.' Islam and Christian-Muslim Relations 26(1): 33-52.doi: 10.1080/09596410.2014.967930.

Baderoon, G. and Decker, A. C. (2018). “African Feminisms Cartographies for the Twenty-First Century”. Meridians. 17 (2): 219-231. doi:10.1215/15366936-7176384. ISSN 1536-6936.

Berkey, L., Franzen, T., \&Leitz, L. (2000). Feminist Responses to Stigma: Building Assets in African American Adolescent Girls. Feminist Teacher, 13(1), 35-47. Retrieved from www.jstor.org/stable/40545930

Bureau of Counterterrorism (2014) "Country Reports on Terrorism 2013". U.S. Department of State. Retrieved from https://www.state.gov/documents/organization/225886.pdf Chatterjee, S. (2016-02-01). "What Does It Mean to Be a Postcolonial Feminist? The Artwork of Mithu Sen". Hypatia. 31 (1): 22-40. doi:10.1111/hypa.12225. ISSN 1527-2001.

Chiluwa, I. and Ifukor, I. (2015) “War against our Children': Stance and evaluation in \#BringBackOurGirls campaign discourse on Twitter and Facebook' Discourse \& Society 2015,Vol. 26(3) 267-296. Sage Publications[Online]doi. org/10.1177/0957926514564735.

Dixon, K. (2014) "Feminist Online Identity: Analyzing the Presence of Hashtag Feminism." Journal of Arts and Humanities 3(7): 34-40. Ohio Humanities and News Retrieved from http://www.ohiohumanities.org/betty-friedan-the-threewaves-of-feminism/.

Drucker, S. N. (2018) "Betty Friedan: The Three Waves of Feminism" Ohio Humanities. Retrieved from http://www. ohiohumanities.org/betty-friedan-the-three-waves-of-feminism/.

Elhassan, S. (2018, June 21). Sara Elhassan: In Sudan, the \#JusticeForNoura campaign gave a voice to the voiceless CNN Retrieved from https://edition.cnn.com/2018/06/21/opinions/noura-hussein-social-media-campaign-elhassanasequals-intl/index.html.

Gamble, S. (ed.) (2001) The Routledge Companion to Feminism and Postfeminism. New York: Routledge.

Hansen, A. and Machin, D.(2013) Media and Communication Research Methods. Palgrave Macmillan.

Hill, J.N (2014) Boko Haram, the Chibok Abductions and Nigeria's Counterterrorism Strategy Vol7(7), Retrieved from https://ctc.usma.edu/boko-haram-the-chibok-abductions-and-nigerias-counterterrorism-strategy/.

Ihle, A. (2009) "A Critical Discourse of African Feminism as an Exponent of Feminist Theory" Nelson Mandela Metropolitan University, Faculty of Arts, School of Governmental and Social Science, SSA 204 - Women in Africa

Ingerson, K and Bruce, J. (2013) Leadership in the Twitterverse. Journal of Leadership Studies, 7(3):74-83 Retrieved from https://www.researchgate.net/publication/271814511_Leadership_in_the_Twitterverse/citations.

Kennedy, A. and Prock, K. (2016) "I Still Feel Like I Am Not Normal”: A Review of the Role of Stigma and Stigmatization Among Female Survivors of Child Sexual Abuse, Sexual Assault, and Intimate Partner Violence. Sage Journal, V 19(5), pp 512-527.

Mackintosh, E. and Elbagir, N. (2018, May 11) Bites and a broken bed: New details in case of Sudan teen who killed rapist husband. CNN Retrieved from https://edition.cnn.com/2018/05/24/africa/noura-hussein-sudan-appeal-intl/ index.html.

Maiangwa, B. and Agbiboa, D. E (2013) Boko Haram, Religious Violence, and the Crisis of National Identity in Nigeria Towards a Non-killing Approach Retrieved from https://doi.org/10.1177/0169796X13503198.

Maerten, M. (2004, July) “African Feminism” RoSa FactsheetNr. 34

Mama, A. (2005). "Gender Studies for Africa's Transformation", in Mkandawire, T. ed. African Intellectuals: Rethinking Politics, Language, Gender and Development, Dakar: CODESRIA

Maxfield, Mary (2015) 'History Retweeting Itself: Imperial Feminist Appropriations of "Bring Back Our Girls"' Feminist Media Studies [Online] Available at: http://dx.doi.org/10.1080/14680777.2015.1116018 [retrieved on 2018-11-28.

McEwan, C. (2001) "Postcolonialism, Feminism and Development: Intersections and Dilemmas". Sage Journals 1 (2), 93- 111. https://doi.org/10.1177/146499340100100201.

Mendes, K., Ringrose, J., and Keller, J. (2018) \#MeToo and the promise and pitfalls of challenging rape culture through digital feminist activism. European Journal of Women's Studies. Retrieved from https://journals.sagepub.com/doi/ abs/10.1177/1350506818765318. 
Morgan, R. (1970) Sisterhood is Powerful: An Anthology of Writings from the Women's Liberation Movement. New York: Vintage Books. ISBN-13: 978-0394705392

Munro, E. (2013) Feminism: A Fourth Wave? Sage Journal V 4 (2), pp: 22-25.

Mutume, G. (2005) African Women Battle for Equality. Africa Renewal. Retrieved from: https://www.un.org/africarenewal/magazine/july-2005/african-women-battle-equality.

Nigeria: Criminal Code Act [Nigeria], Cap C38 LFN 2004, 1 June 1916 (amended version of 1990), Retrieved from: https:// www.refworld.org/docid/49997ade1a.html

Nkealah, N. (2016). “(West) African Feminisms and Their Challenges”. Journal of Literary Studies. 32 (2): $61-$ 74. doi:10.1080/02564718.2016.1198156.

Omeni, A. (2017) Counter-Insurgency in Nigeria The Military and Operations against Boko Haram, 2011-2017, $1^{\text {st }}$ Edition, Routledge Publications.

Oyewole, S. (2016) 'Rescuing Boko Haram's Schoolgirl Victims.' New Zealand International Review 41(1): 25-28.

Parisi, L. (2010) Feminist Perspectives on Human Rights. International Studies Association and Oxford University Press. Online Publication Retrieve from https://oxfordre.com/internationalstudies/view/10.1093/acrefore/9780190846626.001.0001/ acrefore-9780190846626-e-48.

Pendergrass, W. S. (2015) '\#NotAllMen, \#BringBackOurGirls\& \#YesAllWomen: Three Months of Gender Discussion in the Age of Twitter.' Issues in Information Systems 16(1): 60-68.

Poster, M. (2009) Global Media and Culture. New Literary History 39, 685-703.

Rape case: Justice for the late Ochanya (2018, November 12) Punch Nigeria Retrieved from https://punchng.com/ rape-case-justice-for-the-late-ochanya.

Segun, M. and Muscati S. (2015) “\#BringBackOurGirls but Also \#HelpTheEscaped”. Human Rights Watch. Retrieved from https://www.hrw.org/news/2015/04/14/bringbackourgirls-also-helptheescaped.

Statista (2019) "Fastest growing online populations based on relative year-on-year user growth as of January 2019" [Online] Retrieved fromhttps:/www.statista.com/statistics/292488/fastest-growing-internet-populations/.

Stolz, J. and Le Faure P. (1997) The Secret Suffering of African Women RivInferm. 1997 Oct-Dec;16(4):241-3. Italian. PubMed PMID: 9510829

Smith, M. (2015) Boko Haram: Inside Nigeria's Unholy War.' London: I.B. Tauris.

Tomchak, A. (2014, May 6) \#BBCtrending: How a million people called to \#BringBackOurGirls BBC News Retrieved from https://www.bbc.com/news/blogs-trending-27298696.

UNICEF (2014) A Statistical Snapshot of Violence Against Adolescent girls Retrieved from: https://www.unicef.org/ publications/files/A_Statistical_Snapshot_of_Violence_Against_Adolescent_Girls.pdf.

UN Women (2018) Statement: Appeal for clemency for Noura Hussein Retrieved from: https://www.unwomen.org/en/ news/stories/2018/5/statement-appeal-for-clemency-for-noura-hussein.

Wodak R. and Michael Meyer (2001). Methods of Critical Discourse Analysis. Sage Publications. ISBN 978-0-7619-6154-3.

\section{BIOGRAPHICAL NOTE}

Blessing Datiri is a PhD candidate at the Institute of Literary and Cultural Studies, University of Debrecen, Hungary. Her research focuses on analyzing the impact of new media on gender activism in sub-Saharan Africa by evaluating why and how the \#BringBackOurGirls campaign was conducted on Social media platforms after over 270 Nigerian girls were captured by Boko Haram in 2014. Her other interests include Mass Communication, New Media and Conflict Resolution. Prior to starting the PhD program, Blessing had teaching and communications advisory experience in Nigeria. She holds a BA Degree in Mass Communications from the University of Jos in Nigeria and an MA in Communications from the University of Bedfordshire, United Kingdom. 